\title{
Status Sosial Orang Tua dan Prestasi Akademik Siswa
}

\author{
Muhammad Syarif Hidayatullah
}

\author{
Darmawan Manda \\ Universitas Negeri Makassar \\ darmanmanda@unm.ac.id
}

\author{
Suardi \\ Universitas Muhammadiyah Makassar \\ suardi@unismuh.ac.id
}

\begin{abstract}
ABSTRAK
Masalah utama dalam penelitian ini adalah keterkaitan dan hubungan antara status sosial ekonomi orang tua terhadap prestasi siswa. Tujuan penelitian ini adalah (i) Untuk mengetahui gambaran tentang status sosial ekonomi orang tua siswa. (ii) Untuk mengetahui tingkat prestasi akademik siswa. (iii) Untuk mengetahui keterkaitan status sosial ekonomi orang tua terhadap tingkat prestasi siswa di Kecamatan Tanete Riaja Kabupaten Barru. Jenis penelitian yang dilakukan adalah penelitian kualitatif yang bertujuan mengetahui hubungan status sosial ekonomi terhadap prestasi siswa. informan di tentukan secara purposive sampling berdasarkan karakteristik informan yang telah ditetapkan yaitu orang tua siswa, tenaga pendidik, masyarakat, pemerintah dan siswa. Tekhnik pengumpulan data yaitu observasi, dokumentasi dan wawancara mendalam. Teknik analisis data melalui berbagai tahapan yaitu reduksi data, penyajian data, dan penarikan kesimpulan. Sedangkan teknik keabsahan data menggunakan triangulasi sumber, waktu dan teknik. Hasil penelitian ini menunjukkan bahwa (i) Tingkat status sosial ekonomi orang tua siswa di kecamatan Tanete Riaja Kabupaten Barru dapat dikatakan sebagian besar berstatus sosial ekonomi menengah ke bawah. (ii) siswa di kecamatan Tanete Riaja Kabupaten Barru, memiliki prestasi yang sangat baik. (iii) Keterkaitan Status sosial ekonomi orang tua siswa dengan prestasi akademik siswa, dapat dikatakan tidak memiliki keterkaitan yang signifikan.
\end{abstract}

Kata Kunci : Status, Sosial, Ekonomi.

\section{PENDAHULUAN}

Seiring dengan perkembangan zaman yang setiap waktu semakin meningkat terutama dalam bidang pendidikan, pendidikan merupakan hal yang bersifat mutlak bagi setiap manusia dan tidak dapat dipisahkan dari kehidupan seseorang, keluarga maupun kehidupan berbangsa dan bernegara karena pendidikan membentuk pribadi-pribadi yang tangguh, berkualitas dan memiliki ilmu pengetahuan yang tinggi dan sesuai dengan perkembangan zaman. Pendidikan memiliki peran yang sangat penting dalam upaya meningkatkan kualitas sumber daya manusia baik dari sisi social, spiritual, intelektual, maupun kemampuan profesional karena manusia merupakan kekuatan utama pembangunan dengan demikian mutu pendidikan akan sangat menentukan tingkat keberhasilan pembangunan. Dan pembangunan akan juga mempengaruhi perkembangan 
dengan mengelola pendidikan itu sendiri. Pendidikan memainkan peranan penting dalam mengasah keterampilan seorang individu yang membuat dia sebagai orang yang siap untuk mencari dan memperoleh pekerjaan

Memasuki era globalisasi dan modernisasi dewasa ini, perkembangan ilmu pengetahuan dan teknologi mengalami perkembangan pesat. Tuntutan masyarakat semakin kompleks dan persaingan sangat ketat. Hal ini harus didukung dengan Sumber Daya Manusia (SDM) yang berkualitas. Untuk meningkatkan Sumber Daya Manusia (SDM) dilakukan melalui jalur pendidikan. Pendidikan merupakan faktor pendukung utama terbentuknya manusia yang produktif dan kreatif guna terciptanya masyarakat yang sejahtera dan makmur serta memajukan bangsa dan negara. Dalam arti luasnya, pendidikan mengandung pengertian mendidik, membimbing, mengajar, dan melatih setiap individu. Sebagaimana dalam Undang-undang No 20 Tahun 2003 tentang sistem pendidikan nasional pasal I ayat I di nyatakan bahwa: Pendidikan adalah "usaha sadar dan rencana untuk mewujudkan suasana belajar dan proses pembelajaran agar peserta didik secara aktif mengembangkan potensi dirinya untuk memiliki kekuatan spiritual keagamaan, pengendalian diri, kepribadian, kecerdasan, akhlak mulia serta keterampilan yang diperlukan dirinya, masyarakat, bangsa dan Negara. Tujuan pendidikan nasional berdasarkan UU RI NO. 20 tahun 2003 tentang Sistem Pendidikan Nasional, sebagai berikut: Pendidikan nasional bertujuan untuk berkembangnya potensi peserta didik agar menjadi manusia yang beriman dan bertaqwa kepada Tuhan YME, berakhlak mulia, sehat, berilmu, cakap, kreatif, mandiri dan menjadi warga negara yang demokratis serta bertanggung jawab.

Dikatakan bahwa orang tua yang berstatus sosial ekonomi tinggi, tidaklah banyak mengalami kesulitan dalam proses pendidikan anaknya. Sebaliknya, bagi orang tua yang berstatus sosial ekonomi rendah maka akan banyak mengalami kesulitan dalam proses pendidikan anaknya. Dalam proses pembelajaran diperlukan sarana penunjang yang terkadang mahal. Akibatnya bagi orang tua yang tidak mampu memenuhi sarana penunjang tersebut, maka anak akan terhambat dalam proses pembelajaran. Keluarga mempunyai pengaruh terhadap proses perkembangan anak karena keluarga adalah lembaga sosial pertama dalam hidup manusia. Didalam keluarga, orang tua memiliki tugas dan kewajiban dalam memenuhi seluruh kebutuhan pendidikan anak, terutama dalam hal finansial. Berdasarkan uraian di atas, peneliti tertarik untuk mengadakan penelitian tentang bagaimana pengaruh status sosial orang tua terhadap tingkat prestasi 
akademik siswa di kecamatan tanete riaja kabupaten barru khususnya pada MA Muhammadiyah Ele.

\section{LANDASAN TEORI}

Stratifikasi sosial atau pelapisan sosial secara umum dapat diartikan sebagai pembedaan atau pengelompokan anggota masyarakat secara vertikal. Stratifikasi sosial merupakan gejal sosial yang sifatnya umum pada setiap masyarakat. Bahkan pada zaman Yunani Kuno, Aristoteles telah menyatakan bahwa di dalam tiap-tiap negara selalu terdapat tiga unsur, yaitu mereka yang kaya sekali, mereka yang melarat, dan mereka yang berada di tengah-tengahnya. Pitirim A.Sorokin dalam (Sadam Ardi 2013:2) menyatakan bahwa social stratification adalah pembedaan penduduk atau masyarakat ke dalam kelas-kelas secara bertingkat (hierarkis). Perwujudannya adalah adanya lapisanlapisan di dalam masyarakat. Setiap lapisan itu disebut dengan strata sosial. Ditambahkan bahwa stratifikasi sosial merupakan ciri yang tetap pada setiap kelompok sosial yang teratur. Lapisan-lapisan di dalam masyarakat memang tidak jelas batas-batasnya, tetapi tampak bahwa setiap lapisan akan terdiri atas individu-individu yang mempunyai tingkatan atau strata sosial yang secara relatif adalah sama. Menurut Soerjono Soekanto dalam (Sadam Ardi 2006:3), selama pada masyarakat terdapat sesuatu yang dihargai maka hal itu akan menjadi bibit yang menumbuhkan adanya sistem berlapis-lapis. Barang atau sesuatu yang dihargai pada masyarakat mungkin berupa uang atau benda-benda yang bernilai ekonomis, mungkin juga berupa tanah, kekuasaan, ilmu pengetahuan, ketaatan dalam beragama, atau mungkin juga keturunan dari keluarga yang terhormat.

Kedudukan di atas tidaklah limitatif karena masih ada ukuran yang lain yang dapat digunakan, akan tetapi ukuran-ukuran di atas sangat menentukan sebagai dasar timbulnya sistem lapisan dalam masyarakat tertentu. Pada beberapa masyarakat tradisional di Indonesia, golongan pembuka tanahlah yang dianggap memiliki status yang paling tinggi, menyusul para pemilik tanah, setelah itu mereka yang hanya memiliki tanah pekarangan rumah saja. Dalam masyarakat perkotaan status sosial ditentukan oleh standar keahlian yang dimiliki atau berada pada standar penilaian ilmu pengetahuan. Di dalam uraian tentang teori lapisan sosial senantiasa dijumpai istilah kelas sosial (social class). Seperti yang sering terjadi dengan beberapa istilah lain dalam sosiologi, maka istilah kelas, juga tidak selalu mempunyai arti yang sama. Walaupun pada hakikatnya mewujudkan sistem kedudukan-kedudukan yang pokok dalam masyarakat. Penjumlahan kelas-kelas dalam masyarakat disebut class-system artinya, semua orang dan keluarga 
yang sadar akan kedudukan mereka itu diketahui dan diakui oleh masyarakat umum. Dengan demikian, maka pengertian kelas adalah paralel dengan pengertian lapisan tanpa membedakan apa dasar lapisan itu baik faktor uang, tanah, kekuasaan atau dasar lainnya.

Kecerdasan ialah istilah umum yang digunakan untuk menjelaskan sifat pikiran yang mencakup sejumlah kemampuan, seperti kemampuan menalar, merencanakan, memecahkan masalah, berpikir abstrak, memahami gagasan, menggunakan bahasa, dan belajar. Kecerdasan erat kaitannya dengan kemampuan kognitif yang dimiliki oleh individu. Kecerdasan dapat diukur dengan menggunakan alat psikometri yang biasa disebut sebagai tes IQ. Ada juga pendapat yang menyatakan bahwa IQ merupakan usia mental yang dimiliki manusia berdasarkan perbandingan usia kronologis. Terdapat beberapa cara untuk mendefinisikan kecerdasan. Dalam beberapa kasus, kecerdasan bisa termasuk kreativitas, kepribadian, watak, pengetahuan, atau kebijaksanaan. Namun, beberapa psikolog tak memasukkan hal-hal tadi dalam kerangka definisi kecerdasan. Kecerdasan biasanya merujuk pada kemampuan atau kapasitas mental dalam berpikir.

Prestasi akademik adalah perubahan dalam hal kemampuan yang disebabkan karena proses belajar. Bentuk hasil proses belajar dapat berupa pemecahan tulisan atau lisan, keterampilan dan pemecahan masalah yang dapat diukur dan dinilai dengan menggunakan tes yang terstandar. Hal ini didukung oleh pernyataan Soemantri yang menyatakan prestasi akademik adalah hasil yang dicapai siswa dalam kurun waktu tertentu pada mata pelajaran tertentu yang diwujudkan dalam bentuk angka dan dirumuskan dalam rapor

Prestasi adalah hasil dari suatu kegiatan yang telah dikerjakan, diciptakan, baik secara individual maupun kelompok. Prestasi tidak akan pernah dihasilkan tanpa suatu usaha yang baik berupa pengetahuan maupun berupa keterampilan. Prestasi menyatakan hasil yang telah diicapai, dilakukan, dikerjakan, dan sebagainya, dengan hasil yang menyenangkan hati diperoleh dengan jalan keuletan kerja. Sobur dalam (Gayartri 2006) menyatakan bahwa prestasi akademik merupakan perubahan dalam hal kecakapan tingkah laku, ataupun kemampuan yang dapat bertambah selama beberapa waktu dan tidak disebabkan proses pertumbuhan, tetapi adanya situasi belajar. Perwujudan bentuk hasil proses belajar tersebut dapat berupa pemecahan lisan maupun tulisan, dan keterampilan serta pemecahan masalah llangsung dapat diukur atau dinilai dengan menggunakan tes yang standar.

Menurut Setiawan dalam (Naam 2008) prestasi akademik adalah istilah untuk menunjukkan suatu pencapaian tingkat keberhasilan tentang suatu tujuan, karena suatu 
usaha belajar telah dilakukan oleh seseorang secara optimal. Adanya kebutuhan untuk mendapatkan umpan balik atas pekerjaan yang dilakukan sehingga dapat diketahui dengan cepat hasil yang diperoleh dari kegiatannya, lebih baik atau lebih buruk. Menghindari tugas-tugas yang sulit atau terlalu mudah, akan tetapi memilih tugas yang tingkat kesulitannya sedang. Inovatif, yaitu dalam melakukan proses pekerjaan dilakukan dengan cara yang berbeda, efisien dan lebih baik dari yang sebelumnya. Hal ini dilakukan agar individu mendapatkan cara yang lebih baik dan menguntungkan dalam pencapaian tujuan. Tidak menyukai keberhasilan yang bersifat kebetulan atau karena tindakan orang lain, dan ingin merasakan kesuksesan atau kegagalan disebabkan oleh tindakan individu itu sendiri.

Dengan demikian, individu yang memiliki keinginan untuk berprestasi tinggi adalah individu yang memiliki standar berprestasi, memiliki tanggung jawab pribadi atas apa yang dilakukannya, individu lebih suka bekerja pada situasi dimana dirinya mendapat umpan balik sehingga dapat diketahui seberapa baik tugas yang telah dilakukannya, individu tidak menyukai keberhasilan yang bersifat kebetulan atau karena tindakan orang lain, individu lebih suka bekerja pada tugas yang tingkat kesulitannya menengah dan realistis dalam pencapaian tujuannya, individu bersifat inovatif dimana dalam melakukan tugas selalu dengan cara yang berbeda, efisien, dan lebih baik dari yang sebelumnya. Dengan demikian, individu merasa lebih dapat menerima kegagalannya atas apa yang dilakukannya.

Keadaan sosial ekonomi setiap orang berbeda-beda dan bertingkat, ada yang keadaan sosial ekonominya tinggi, sedang, dan rendah. Sosial ekonomi menurut Abdulsyani adalah kedudukan atau posisi sesorang dalam kelompok manusia yang ditentukan oleh jenis aktivitas ekonomi, pendapatan, tingkat pendidikan, jenis rumah tinggal, dan jabatan dalam organisasi, sedangkan menurut Soerjono Soekanto sosial ekonomi adalah posisi seseorang dalam masyarakat berkaitan dengan orang lain dalam arti lingkungan peraulan, prestasinya, dan hak-hak serta kewajibannya dalam hubunganya dengan sumber daya. Keluarga dengan pendapatan cukup atau tinggi pada umumnya akan lebih mudah memenuhi segala kebutuhan sekolah dan keperluan lain. Berbeda dengan keluarga yang mempunyai penghasilan relatif rendah, pada umumnya mengalami kesulitan dalam pembiayaan sekolah, begitu juga dengan keperluan lainnya.

Menurut Hamalik (2003:161) bahwa keadaan sosial ekonomi yang baik dapat yang menghambat ataupun mendorong dalam belajar. Masalah biaya pendidikan juga merupakan sumber kekuatan dalam belajar karena kurangnya biaya pendidikan akan 
sangat mengganggu kelancaran belajar. Salah satu fakta yang mempengaruhi tingkat pendidikan anak adalah pendapatan keluarga. Tingkat sosial ekonomi keluarga mempunyai pengaruh yang tinggi terhadap prestasi belajar siswa di sekolah, sebab segala kebutuhan anak yang berkenaan dengan pendidikan akan membutuhkan sosial ekonomi orang tua.

\section{METODE PENELITIAN}

Jenis penelitian yang dilakukan adalah penelitian deskriktif kualitatif yaitu pendekatan penelitian dengan data - data yang dikumpulkan berupa kata gambar dan bukan angka. Proses penelitian terdiri dari btahap, sebelum kelapangan, tahap pekerjaan lapangan, analisis data, tahap penulisan laporan, instrument penelitian dalah merupakan alat bantu yang yain seperti lembar observasi dan kamera, informan ditentukan secara purposive sampling, tehnik pengumpuan data yaitu observasi, wawancara, dan dokumentasi. Kemudian dianalisis melalui tahapan pengumpulan data, reduksi data, penyajian data, data yang dikelompokkan, dan penarikan kesimpulan melalui tehnik keabsahan data, triagulasi sumber, waktu, dan tehnik.

\section{PEMBAHASAN}

Berdasarkan karakteristik Stratifikasi sosial, dapat kita temukan beberapa pembagian kelas atau golongan dalam masyarakat. Istilah kelas memang tidak selalu memiliki arti yang sama, walaupun pada hakekatnya mewujudkan sistem kedudukan yang pokok dalam masyarakat. Pengertian kelas sejalan dengan pengertian lapisan tanpa harus membedakan dasar pelapisan masyarakat tersebut. Kelas Sosial atau Golongan sosial mempunyai arti yang relatif lebih banyak dipakai untuk menunjukkan lapisan sosial yang didasarkan atas kriteria ekonomi.Jadi, definisi Kelas Sosial atau Golongan Sosial ialah Sekelompok manusia yang menempati lapisan sosial berdasarkan kriteria ekonomi. Kelas social atau golongan social terbentuk oleh Status Sosial yang disandang seseorang baik itu dari segi ekonomi, maupun kekuasaan. Jadi status social ekonomi sangant erat kaitannya dengan strata sesorang didalam masyarakat. Status social ekonomi dapat kita klasifikasikan menjadi tiga tingkatan yaitu Status social ekonomi tinggi, sedang, dan bawah. Status social ekonomi terbentuk dari status yang disandang seseorang didalam masyarakat baik dari segi ekonomi, pendidikan, maupun keturunan. Status social ekonomi masarakat kecamatan Tanete Riaja cenderung kepada status social ekonomi sedang dan rendah hal itu sesuai dengan hasil observasi, wawancara yang di dapatkan. 
Masyarakat tanete riaja mayoritas berprofesi sebagai petani yang nota bene pendapatannya tergolong menengah kebawah sehingga masyarakat tanete riaja dapat digolongkan pada tingkat status social ekonomi sedang kebawah. MA Muhammadiyah Ele berhasil meluluskan siswa siswanya lima tahun berturut turut, hal ini menjadi suatu kebanggaan tersendiri bagi pihak sekolah karena merupakan suatu prestasi yang membagakan dan juga dapat di jadika contoh bagi sekolah sekolah lain. Siswa yang bersekolah di MA Muhammadiyah Ele Mayoritas bersal dari kecamatan tanete riaja. orang tua siswa yang bersekolah di MA Muhammadiyah Ele terdiri dari bermacam macam profesi (heterogen) mulai dari petani, pedagang Pengusaha, dan PNS. Mayoritas profesi orang tua siswa di MA Muhammadiyah Ele adalah Petani . namun hal ini tidak membuat para siswa terbelakan dalam hal pendidikan hal ini terbukti dari pencapaian siswa yang sangat luar biasa mulai dari unggul di bidang akademik hingga didang ekstrakulikuler. Hal ini juga menenunjukkan tidak ada kaitan antara status social orang tua dengan prestasi seorang anak sebab status social ekonomi orang tua siswa hanyalah salah satu factor yang mempengaruhi prestasi anaknya, masih banyak factor yang turut andil dalam pencapaian prestasi seorang anak salah satunya factor internalnya yang berupa kecerdasan atau IQ.

\section{KESIMPULAN}

Berdasarkan penelitian mengenai pengaruh status sosial ekonomi orang tua siswa terhadap prestasi belajar siswa di kecamatan Tanete Riaja, maka pada bab ini penulis mengemukakan beberapa kesimpulan yaitu tingkat status sosial ekonomi orang tua siswa di kecamatan Tanete Riaja Kabupaten Barru dapat dikatakan sebagian besar berstatus sosial ekonomi menengah ke bawah. Setelah penulis melakjukan penelitian tentang Prestasi Akademik siswa di kecamatan Tanete Riaja kabupaten Barru maka peneliti menarik kesimpulan bahwa siswa di kecamatan Tanete Riaja Kabupaten Barru, memiliki prestasi yang sangat baik. Keterkaitan Status sosial ekonomi orang tua siswa dengan prestasi akademik siswa, dapat dikatakan tidak memiliki keterkaitan yang signifikan, hal ini dapat terlihat dari hasil penelitian yang penulis laksanakan, di mana tingkat status sosial ekonomi orang tua siswa yang sebagian besar menengah ke bawah tidak berdampak pada prestasi akademik siswa di kecamatan Tanete Riaja Kabupaten Barru.

\section{DAFTAR PUSTAKA}

Astrid S. Susanto, (1983) Pengantar Sosiologi, (Jakarata : Bina Aksara 
Desiningrum, D. R. (2015). Kecerdasan Interpersonal Pada Remaja Yang Pernah Menjadi Korban Child Abuse.

Hassan Sadilly (2007) Sosiologi: Menyelami Fenomena Sosial di Masyarakat. PT Grafindo Media Pratama

Henslin, James M. (2007). Sosiologi dengan Pendekatan Membumi, jilid 1,edisi 6. Jakarta: Penerbit Erlangga.

Knopfemacher (dalam Suwono, 1978) Pengertian Mahasiswa. (Online) (http://definisipengertian.com/2012/pengertian-definisi-mahasiswa-menurutpara-ahli/. Di akses pada tanggal 5 januari 2016)

Maftukhah. (2007). Pengaruh Kondisi Sosial Ekonomi Orang Tua Terhadap Prestasi Belajar Geografi Siswa Kelas VIII SMPN 1 Randudongkal Kabupaten Pemalang Tahun 2006/200, skripsi diajukan untuk memperoleh gelar sarjana pendidikan geografi pada UNS,(Online), (digilib.unnes.ac.id/gsdl/collect/skripsi/index/assoc/HASH0152/doc. diakses pada tanggal 1 Januari 2016).

Manginsihi, O., YUNUS, H., \& MOPANGGA, H. (2013). Pengaruh Status Sosial Ekonomi Keluarga Terhadap Prestasi Belajar Siswa Kelas X di SMK Negeri 4 Gorontalo. KIM Fakultas Ekonomi \& Bisnis, 1(1).

Marhaeni, N. (2016). Hubungan kecerdasan emosi dengan prestasi belajar matematika siswa kelas $v$ sekolah dasar segugus i kecamatan wates kabupaten kulon progo tahun ajaran 2015/2016. Basic education, 5(4), 334-343. Nirwana Mahmud skripsi sosial budaya

Nasution, S. (2008). Metode Research (Penelitian Ilmiah). Jakarta: Penerbit Bumi Aksara.

Nasrun. (2008). PrestasiBelajar(www.prestasi.com/belajarnews/0544/saq/html.)diakses pada tanggal 7 Januari 2016).

Opit (2001). Meraih Nilai Akademik Maksimal, (Online, http://www.pend-tinggi.com/ nilai098+akademik/html., diakses pada tanggal 14 Januari 2016)

Oemar, Hamalik. (2003). Metode belajar \& kesulitan-kesulitan belajar. Bandung: tarsito.

Pitirim A.Sorokin dalam Soekanto (2003) Soosiologi Suatu Pengantar. Jakarta: PT Raja Grafindo Persada.

peraturan pemerintah RI No.30 tahun 1990. Pengertian Mahasiswa. https://unpaztoday.wordpress.com/akademik/mahasiswa/Di akses pada tanggal 5 januari 2016)

Qohar. (2007). Prestasi Belajar Akademik, (http://www.prestasi+akademik-/ belajar news/235/saq/html) diakses pada tanggal 14 Januari 2016). 
Sahputra, Naam. (2009). Hubungan Konsep Diri Dengan Prestasi Akademik Mahasiswa S1 Keperawatan Smester III Kalas Ekstensi PSIK FK USU Medan,(repository.usu.ac.id/bitstream/123456789/14291/1/09E00579.pdf diakses pada tanggal 5 januari 2016)

Setiawan. (2008). Meraih Nilai Akademik Maksimal, (Online), http://www.pendtinggi.com/nilai098+akademik/html., diakses pada tanggal 14 Januari 2016)

Soetjiningsih, (2006) Status sosial ekonomi (http://www.prestasi+akademik-/ belajar news/235/saq/html) diakses pada tanggal 14 Januari 2016).

Soemantri (dalam Nurani, 2004) prestasi akademik

Said Gatara, A.A, dan Dzulkiah Said, Moh. (2007). Sosiologi Politik, Konsep dan Dinamika Perkembangan Kajian. Bandung: CV Pustaka Setia.

Said Gatara, A.A, dan Dzulkiah Said, Moh (2007) Sosiologi Politik, Konsep dan Dinamika Perkembangan Kajian. Bandung: CV Pustaka Setia.

Soekanto, Soerjono. (2006). Soosiologi Suatu Pengantar. Jakarta: PT Raja Grafindo Persada.

Soekanto, Soerjono (2003) Soosiologi Suatu Pengantar. Jakarta: PT Raja Grafindo Persada.

Soekanto, Soerjono (2002). Sosiologi Suatu Pengantar. Jakarta: Rajawali PRESS.

Sugiyono, (2009). Metode Penelitian Kuantitatif, Kualitatif, dan R\&D. Bandung: Penerbit Alfabeta.

Sarwono (1978) Pengertian Mahasiswa. (Online http://definisipengertian.com /2012/pengertian-definisi-mahasiswa-menurut-para-ahli/ Di akses pada tanggal 5 januari 2016)

Undang-Undang Dasar Tahun 1945 Republik Indonesia. tentang Sistem Pendidikan Nasional.

UU RI NO. 20 tahun 2003 tentang Sistem Pendidikan Nasional.

YUDHIARTI, N. P. (2016). hubungan kecenderungan trait kepribadian conscientiousness dan agreeableness dengan regulasi diri dalam belajar pada siswa smk nagara di ngawi (doctoral dissertation, uin sunan kalijaga yogyakarta). 